\title{
Islet-reactive T Cells Are a Marker of Preclinical Insulin-dependent Diabetes
}

Leonard C. Harrison, Shirley X. Chu, Henry J. DeAizpurua, Meredith Graham, Margo C. Honeyman, and Peter G. Colman*

Burnet Clinical Research Unit, The Walter and Eliza Hall Institute of Medical Research, and *Endocrine Laboratory,

Royal Melbourne Hospital, Parkville, Victoria 3050, Australia

\section{Abstract}

The destruction of pancreatic islet beta cells in insulin-dependent diabetes mellitus (IDDM) is thought to be $T$ cell mediated. To directly identify islet-reactive $T$ cells in asymptomatic, "preclinical" IDDM individuals with islet cell antibodies (ICA), proliferation of peripheral blood mononuclear cells (PBMC) was measured in the presence of sonicated fetal pig proislets. Stimulation indices (mean \pm SD) for $\left[{ }^{3} \mathrm{H}\right]$ thymidine uptake by PBMC cultured with sonicated proislets were: preclinical IDDM subjects $(n=22) 6.10 \pm 6.50$, recent-onset IDDM subjects $(n=29) 3.66 \pm 3.35$, Graves' disease subjects $(n=6) 2.17 \pm 0.93$, scleroderma subjects $(n=4) 1.65 \pm 0.19$ and normal control subjects $(n=14) 1.63 \pm 0.62$. 68\% $(15 / 22)$ of preclinical IDDM, 41\% (12/29) of recent-onset IDDM and $17 \%(1 / 6)$ of Graves' disease subjects had $T$ cell reactivity greater than the mean +2 SD of controls. $T$ cell reactivity to proislets was tissue specific, and greater in magnitude and frequency than to human insulin.

The majority of preclinical subjects with ICA $>20$ Juvenile Diabetes Foundation (JDF) units $(12 / 15,80 \%)$ or antibodies to a 64-kD islet autoantigen $(11 / 15,73 \%)$ had significant $T$ cell reactivity to proislets. ICA $>40 \mathrm{JDF}$ units, a strong prognostic marker for progression to clinical IDDM, was an absolute index of $T$ cell reactivity. Overall, the frequency of $T$ cell reactivity in preclinical subjects, $68 \%(15 / 22)$, was comparable to that of ICA $>20$ JDF units or 64-kD antibodies.

Greater $\mathrm{T}$ cell reactivity to proislets in preclinical subjects accords with the natural history of autoimmune beta cell destruction. The direct assay of islet-reactive $T$ cells in peripheral blood may have prognostic significance for the development of clinical IDDM and should facilitate identification of the primary target autoantigen(s). (J. Clin. Invest. 1992. 89:11611165.) Key words: preclinical diabetes $\bullet$ autoreactive $T$ cells • islet antibodies • fetal pig proislets

\section{Introduction}

Insulin-dependent diabetes mellitus (IDDM) ${ }^{1}$ results from progressive destruction of pancreatic islet beta cells, a process be-

Address correspondence to Professor Leonard C. Harrison, Burnet Clinical Research Unit, The Walter and Eliza Hall Institute of Medical Research, Parkville, Victoria 3050, Australia.

Received for publication 9 September 1991 and in revised form 28 October 1991.

1. Abbreviations used in this paper: GAD, glutamic acid decarboxylase; HEM, Hanks'/Eagle's medium; IAA, insulin autoantibodies; IDDM, insulin-dependent diabetes mellitus; JDF, Juvenile Diabetes Foundation.

J. Clin. Invest.

(c) The American Society for Clinical Investigation, Inc.

0021-9738/92/04/1161/05 \$2.00

Volume 89, April 1992, 1161-1165 lieved to be mediated by autoreactive $\mathrm{T}$ cells (1). In the spontaneous animal models of IDDM, the non-obese diabetic mouse $(2,3)$ and Bio-Breeding rat $(4)$, the pancreatic islets become infiltrated successively with macrophages, CD4 and then CD8 $\mathrm{T}$ cells before beta cell destruction. In a postmortem pancreas from a human with recent-onset IDDM the islets were found to be infiltrated predominantly by CD8 T cells (5). Direct evidence for the diabetogenic role of $T$ cells is the ability of $T$ cells to transfer diabetes from nonobese diabetic mice (6) or BioBreeding rats (7) to syngeneic, nondiabetic animals.

Recent studies in humans with IDDM have identified T cells in peripheral blood that react to islet antigens. De Berardinis et al. (8) generated CD4 $\mathrm{T}$ cell clones against human islets and Roep et al. (9) generated CD4 T cell lines to a $38 \mathrm{kD}$ protein fraction of insulin secretory granule membranes. In a preliminary report (10), we documented the direct reactivity of peripheral blood $\mathrm{T}$ cells to intact human islets or fetal pig proislets in preclinical IDDM and recent-onset clinical IDDM subjects. The present study analyzes peripheral blood $T$ cell reactivity to sonicated fetal pig proislets in relation to the conventional autoantibody markers of preclinical IDDM. Fetal pig proislets were used because of their ready availability compared to adult human islets and their potential as an islet source for transplantation.

\section{Methods}

Subjects. Experimental procedures were performed according to protocols approved by the Institutional Board of Medical Research and Human Ethics Committee. Preclinical IDDM subjects (11 female, 11 male; mean age $29.2 \mathrm{yr}$, range 6-48) were defined operationally as asymptomatic, first degree relatives of persons with IDDM who, in our prediabetes family screening program, were found to have islet cell antibodies (ICA) at a level $\geq 20$ Juvenile Diabetes Foundation (JDF) units. The designation preclinical IDDM is not meant to imply that progression to clinical diabetes is inevitable. These subjects had an intravenous glucose tolerance test and were offered repeat tests every six months for ICA, insulin autoantibodies, autoantibodies (64 KAb) to a $64-\mathrm{kD}$ islet protein tentatively identified as beta cell glutamic acid decarboxylase $(10,11)$, and islet-reactive $T$ cells. In the intravenous glucose tolerance test the sum of the plasma insulin levels at 1 and 3 $\min$ after $0.5 \mathrm{~g} / \mathrm{kg}$ i.v. glucose was used as a measure of first phase insulin release. The range in 25 normal adults (mean age $31 \mathrm{yr}$ ) was 32-230 mU/liter, with a mean of $95 \mathrm{mU} / \mathrm{liter}$ and a median of 88 $\mathrm{mU} /$ liter. Data for individual preclinical subjects are listed in Table $\mathrm{I}$. Recent-onset IDDM subjects ( 16 female, 13 male; mean age $15.5 \mathrm{yr}$, range 7-36) were insulin-dependent, having presented with typical clinical features of IDDM in the previous $6 \mathrm{wk}$; the older patients were tested for autoantibodies within two weeks of starting insulin. Control subjects were either patients with Graves' disease ( 4 female, 2 male; mean age $39.3 \mathrm{yr}$, range 24-59) or scleroderma ( 3 female, 1 male; mean age $48.0 \mathrm{yr}$, range 46-51), or were normal volunteers ( 6 female, 8 male; mean age $28.0 \mathrm{yr}$, range 7-51); none had detectable ICA, insulin autoantibodies or $64 \mathrm{KAb}$. Subjects with Graves' disease had recent-onset clinical hyperthyroidism with thyroid stimulating hormone receptor antibodies and were taking the antithyroid drug, carbimazole. Those with scleroderma had the subcutaneous calcinosis, Raynaud's phenom- 


\begin{tabular}{|c|c|c|c|c|c|c|c|c|c|}
\hline \multirow[b]{2}{*}{$\begin{array}{l}\text { Pre-Clinical } \\
\text { IDDM } \\
\text { subject }\end{array}$} & \multirow[b]{2}{*}{ Sex } & \multirow[b]{2}{*}{ Age } & \multirow[b]{2}{*}{$\begin{array}{c}\text { IVGTT } \\
1+3 \mathrm{~min} \\
\text { plasma } \\
\text { insulin }\end{array}$} & \multirow[b]{2}{*}{ HLA-DR } & \multirow[b]{2}{*}{$\begin{array}{c}\text { ICA } \\
\text { (JDF units) }\end{array}$} & \multirow[b]{2}{*}{$64 \mathrm{KAb}$} & \multirow[b]{2}{*}{ IAA } & \multicolumn{2}{|c|}{$\begin{array}{l}\text { Stimulation Index of } \\
\text { PBMC to: }\end{array}$} \\
\hline & & & & & & & & $\begin{array}{l}\text { Fetal pig } \\
\text { proislet } \\
\text { sonicate }\end{array}$ & $\begin{array}{c}\text { Human } \\
\text { insulin }\end{array}$ \\
\hline & & & mU/liter & & & & $n U / m l$ & & \\
\hline 1 & $\mathrm{~F}$ & 43 & 143 & 3,4 & 640 & + & 29 & 13 & 3.7 \\
\hline 2 & $\mathbf{F}$ & 48 & 71 & 3,4 & 640 & ++ & -5 & 3.0 & 1.5 \\
\hline 3 & $\mathbf{M}$ & 46 & 97 & 3,4 & 40 & - & 22 & 1.7 & ND \\
\hline 4 & $F$ & 17 & 183 & 3,4 & 40 & - & 8 & 5.3 & 1.4 \\
\hline 5 & $\mathbf{F}$ & 41 & 126 & 3,4 & 20 & ++ & 7 & 1.3 & 2.2 \\
\hline 6 & $\mathbf{F}$ & 41 & 113 & 3,7 & 40 & ++ & 21 & 8.0 & 3.7 \\
\hline 7 & $F$ & 35 & 116 & 3,11 & 20 & ++ & 32 & 10 & 1.2 \\
\hline 8 & $F$ & 39 & 177 & 3,12 & 320 & - & 5 & 3.9 & 2.1 \\
\hline 9 & $\mathbf{F}$ & 44 & 132 & $3,-$ & 20 & - & 14 & 1.5 & 1.8 \\
\hline 10 & $\mathbf{M}$ & 10 & 20 & $3,-$ & 40 & + & 0 & 5.2 & 1.1 \\
\hline 11 & $\mathbf{F}$ & 44 & 79 & $3,-$ & 20 & + & 78 & 26 & 3.3 \\
\hline 12 & $\mathbf{M}$ & 12 & 118 & 4,13 & 320 & - & -12 & 3.2 & 1.2 \\
\hline 13 & $\mathbf{M}$ & 33 & 50 & 4,13 & 20 & ++ & 85 & 5.3 & 4.1 \\
\hline 14 & $\mathbf{F}$ & 22 & 137 & 4,11 & 20 & + & 31 & 1.5 & ND \\
\hline 15 & $\mathbf{M}$ & 15 & 102 & 4,9 & 160 & + & -9 & 5.0 & 0.2 \\
\hline 16 & $\mathbf{M}$ & 48 & 57 & 4,8 & 20 & + & 10 & 2.3 & 1.4 \\
\hline 17 & $\mathbf{F}$ & 40 & 79 & $4,-$ & 80 & + & 30 & 23 & + \\
\hline 18 & $\mathbf{M}$ & 6 & 47 & 1,4 & 40 & + & 68 & 1.7 & 1.1 \\
\hline 19 & $\mathbf{M}$ & 30 & 160 & 2,3 & 40 & + & 17 & 3.0 & 3.4 \\
\hline 20 & $\mathbf{M}$ & 12 & 121 & 1,3 & 40 & - & 51 & 1.6 & 1.2 \\
\hline 21 & $\mathbf{M}$ & 10 & 44 & ND & 80 & + & 27 & 5.3 & 3.0 \\
\hline 22 & $\mathbf{M}$ & 7 & $\mathrm{ND}^{*}$ & ND & 40 & - & 19 & 3.3 & 0.8 \\
\hline
\end{tabular}

*ND, not done.

enon, esophageal dysmotility, sclerodactyly, and telangiectasia variant of the disease with anti-centromere antibodies.

Fetal pig tissues. Pancreata of 10-13-wk-old fetal pigs were minced with sterile scissors in ice-cold Hanks'/Eagle's medium (HEM) in sterile tubes, washed with $\mathrm{HEM}$ and incubated at $37^{\circ} \mathrm{C}$ with collagenase (Sigma Type XI; Sigma Chem. Co., St. Louis, MO) $2.5 \mathrm{mg} / \mathrm{ml}$ in $5 \mathrm{ml}$ of HEM. The suspension was shaken vigorously every 2-3 min and after at least $10 \mathrm{~min}$ when large tissue fragments were no longer observed the digest was washed twice with cold HEM, the pellet suspended in Dulbecco's minimal essential medium (DME) without serum, and cultured at $37^{\circ} \mathrm{C}$ in a $10 \% \mathrm{CO}_{2}$ humidified incubator. After 2-3 d, acinar tissue degenerated and proislets were passaged into fresh culture medium and handpicked for experiments after 6-10 d.

Cell suspensions from fetal pig thyroid, liver, and kidney were prepared by digesting minced tissues in $2.5 \mathrm{mg} / \mathrm{ml}$ collagenase (Sigma Type V), followed by washing in phosphate-buffered saline (PBS)-10 mM EDTA and then PBS. Handpicked proislets $(5-10,000)$ or dispersed thyroid, liver, or kidney cells $\left(\sim 5 \times 10^{5}\right)$ were sonicated $(50 \mathrm{~Hz}$, $2 \mathrm{~min}$ ) in $500 \mu \mathrm{l}$ of PBS in a sterile microfuge tube. Sonicates were adjusted to a protein concentration of $30 \mu \mathrm{g} / \mathrm{ml}$ (Bio-Rad method; Bio-Rad Labs, Chem Div., Richmond, CA), aliquoted and stored at $-70^{\circ} \mathrm{C}$. Sonicates of proislets at a protein concentration of $1.5 \mu \mathrm{g} / \mathrm{ml}$ contained $\sim 30 \mathrm{ng} / \mathrm{ml}$ of immunoreactive insulin.

$T$ cell proliferation assay. Peripheral blood mononuclear cells (PBMC) were isolated on a Ficoll-Hypaque density gradient, washed and resuspended in human tonicity RPMI 1640 medium containing $20 \mathrm{mM}$ Hepes, $10^{-5} \mathrm{M}$ 2-mercaptoethanol and 5\% heat-inactivated autologous serum. Aliquots of $200 \mu \mathrm{l}\left(4 \times 10^{5}\right.$ cells) were transferred into wells of a 96-well, flat-bottomed plate (Linbro, Flow Laboratories, Hamden, CT). Aliquots $(10 \mu \mathrm{l})$ of fetal pig tissue sonicates (final concentration $0.38,0.75$, or $1.5 \mu \mathrm{g} / \mathrm{ml}$ ) or human insulin (final concentra- tion $0.05,0.1$ or $0.2 \mu \mathrm{g} / \mathrm{ml}$ ) were added to quadruplicate wells. Plates were incubated in a $5 \% \mathrm{CO}_{2}$ humidified incubator for $7 \mathrm{~d}$; $\left[{ }^{3} \mathrm{H}\right]$ thymidine $(1 \mu \mathrm{Ci})$ was added to each well for the last $12-18 \mathrm{~h}$. The cells were then harvested onto glass fiber filters and incorporated radioactivity measured by liquid scintillation spectrometry. The median value of quadruplicate wells (i.e., the mean of the two central values) was determined and the results expressed as the maximum stimulation index, i.e., maximum median counts per minute with antigen/median counts per minute without antigen. The interassay coefficient of variation (SD $\div$ mean $\times 100$ ) of stimulation indices to proislet sonicate in control and preclinical IDDM subjects ranged from 13 to $22 \%$.

Autoantibody assays. ICA were measured in serially diluted serum by indirect immunofluorescence on frozen sections of human, organ donor pancreas and expressed in JDF units relative to reference control sera. IAA were measured by radioimmunoassay (12) with a normal range of -15 to $+40 \mathrm{nU}$ insulin bound per $\mathrm{ml}$ of serum. Both ICA and IAA assays have been included in all International Workshops on Standardization.

Antibodies to the $64-\mathrm{kD}$ protein were detected in an immunoprecipitation assay using solubilized fetal pig proislets. Handpicked proislets $(\sim 2,000)$ were biosynthetically labeled with $\left.0.5 \mathrm{mCi} / \mathrm{ml} \mathrm{[}{ }^{35} \mathrm{~S}\right] \mathrm{me}-$ thionine (Amersham International, Amersham, Bucks, UK) in $4 \mathrm{ml}$ methionine-free Dulbecco's minimal essential medium containing $0.5 \%$ dialyzed, heat-inactivated fetal calf serum, overnight at $37^{\circ} \mathrm{C}$. Washed, labeled islets were extracted with $1 \%$ Triton X-100 in solubilization buffer ( $50 \mathrm{mM}$ Hepes, $\mathrm{pH} 7.5,150 \mathrm{mM} \mathrm{NaCl}, 10 \%$ glycerol, 1.5 $\mathrm{mM} \mathrm{MgCl} 2,1 \mathrm{mM}$ EDTA, $0.15 \mathrm{U} / \mathrm{ml}$ aprotinin, $10 \mu \mathrm{g} / \mathrm{ml}$ leupeptin, 1 $\mathrm{mM}$ phenylmethylsulphonyl fluoride), for $1 \mathrm{~h}$ at $4^{\circ} \mathrm{C}$ with gentle rotation, and centrifuged at $100,000 \mathrm{~g}$ for $30 \mathrm{~min}$ at $4^{\circ} \mathrm{C}$. The supernatant extract was immediately precleared by incubating, for $2 \mathrm{~h}$ at $4^{\circ} \mathrm{C}, 100$ $\mu \mathrm{l}$ aliquots with $25 \mu \mathrm{l}$ Sepharose-protein $\mathrm{A}$ to which had been prebound 


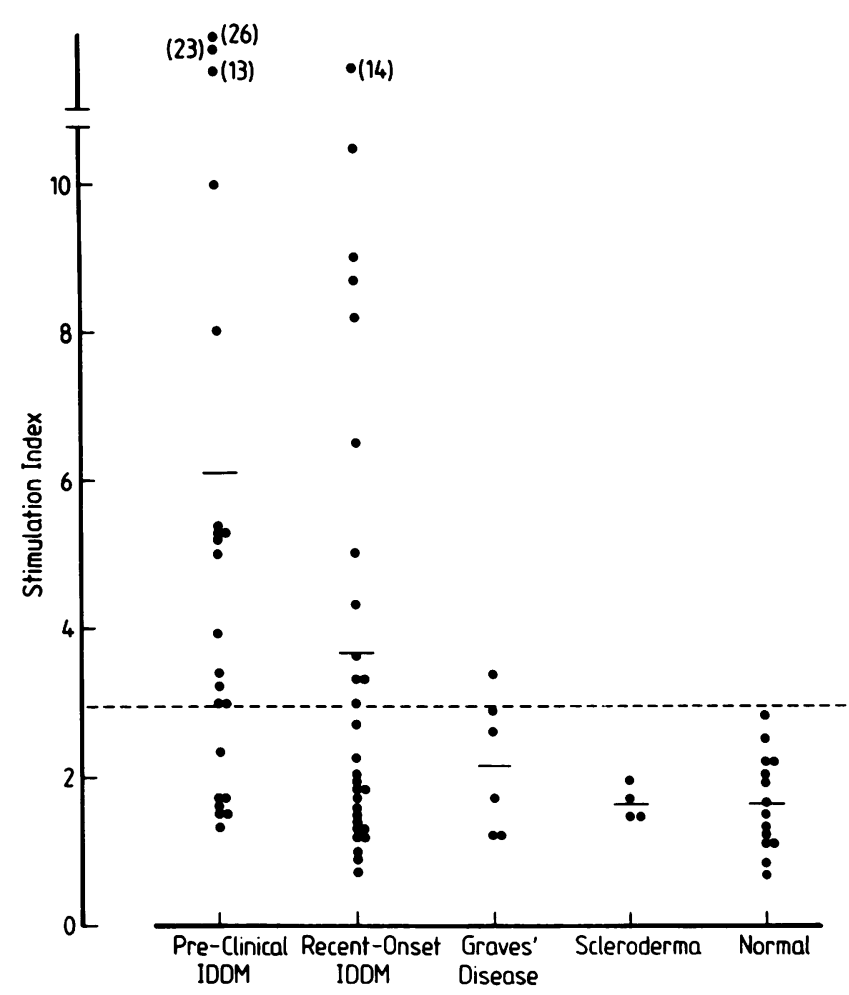

Figure 1. Reactivity of peripheral blood $\mathrm{T}$ cells to sonicated fetal pig proislets expressed as stimulation indices of $\left[{ }^{3} \mathrm{H}\right]$ thymidine uptake. The horizontal bars denote mean values and the dotted line the mean $+2 \mathrm{SD}$ of the normal group.

immunoglobulins (Ig) in $10 \mu \mathrm{l}$ of normal human serum. After centrifugation, the supernatant was incubated overnight at $4^{\circ} \mathrm{C}$ with $25 \mu \mathrm{l}$ of Sepharose-protein A to which had been prebound Ig in $2 \mu \mathrm{l}$ of test serum. After centrifugation, the precipitates were washed once in phosphate-buffered saline (PBS), $0.15 \mathrm{M} \mathrm{NaCl}, 0.2 \%$ Triton $\mathrm{X}-100$ and twice with PBS/0.2\% Triton X-100, then solubilized by boiling for 3 min in SDS sample buffer and analyzed by $10 \%$ SDS-PAGE under reducing conditions. Gels were stained with $0.2 \%$ Coomassie Blue R-250 (Bio-Rad Laboratories), dried and autoradiographed at room temperature using $\beta$ Max Hyperfilm (Amersham), and intensifying screens (Lightning Plus; DuPont Instruments, Wilmington, DE). The intensity of a band at $64 \mathrm{kD}$ was graded visually as,+++ , or +++ .

Statistics. The significance of the difference between groups was determined by the Wilcoxon two-sample test. The correlation coefficient between paired samples was determined by Spearman's rank test.

\section{Results}

The mean \pm SD stimulation index of peripheral blood $T$ cells to sonicated fetal pig proislets was $6.10 \pm 6.50$ in the preclinical group $(n=22)$ compared to $3.66 \pm 3.35$ in the recent-onset group $(n=29), 2.17 \pm 0.93$ in the Graves' disease subjects ( $n$ $=6), 1.65 \pm 0.19$ in scleroderma subjects $(n=4)$ and $1.63 \pm 0.62$ in the normal subjects ( $n=14$ ) (Fig. 1). If a significant stimulation index is defined as greater than the mean of normals +2 $\mathrm{SD}(>2.93)$ then $68 \%(15 / 22)$ of preclinical subjects reacted to sonicated proislets compared to $41 \%(12 / 29)$ of recent-onset subjects and $17 \%(1 / 6)$ of Graves' disease subjects.

The mean \pm SD stimulation indices to human insulin did not differ between subject groups, being $2.02 \pm 1.13$ in the preclinical IDDM, 2.31 \pm 2.43 in the recent-onset IDDM, $1.07 \pm 0.12$ in the scleroderma and $1.10 \pm 0.38$ in the normal subjects (Graves' disease subjects were not tested). However, T cell reactivity to insulin, defined as greater than the mean of normals $+2 \operatorname{SD}(>1.90)$, was present in $42 \%(8 / 19)$ of preclinical subjects and $30 \%(6 / 20)$ of recent-onset subjects. In the preclinical group the magnitude of $T$ cell reactivity to sonicated proislets was significantly greater $(P<0.01)$ than to human insulin and there was no correlation between reactivity to sonicated proislets and human insulin.

In a proportion of subjects from each group, $\mathrm{T}$ cell reactivity was measured to sonicates of fetal pig thyroid, liver and kidney cells, as well as proislets (Table II). Except for proislets, there were no differences between the group means. However, three preclinical females, three recent-onset IDDM females and one scleroderma male had stimulation indices to thyroid greater than the mean $+2 \mathrm{SD}$ of the normal subjects.

The associations between significant $T$ cell reactivity to proislets and islet autoantibodies are summarized in Table III. $T$ cell reactivity to sonicated proislets was present in the majority of preclinical subjects with ICA $>20(12 / 15$ or $80 \%)$ or with $64 \mathrm{KAb}(11 / 15$ or $73 \%)$. Seven subjects in the preclinical group had ICA $>40$ JDF units and all had T cell reactivity to sonicated proislets, compared to 8/15 with ICA $<40$ JDF units. The majority of preclinical subjects were IAA negative but most of these $(13 / 18$ or $72 \%)$ had T cell reactivity to sonicated proislets. Furthermore, most of the preclinical subjects $(6 / 8$ or $75 \%$ ) who had $\mathrm{T}$ cell reactivity to human insulin were IAA negative.

Overall, the frequency of $\mathrm{T}$ cell reactivity to sonicated proislets in the preclinical subjects of $68 \%(15 / 22)$ was the same

Table II. PBMC Responses: Stimulation Indices to Fetal Pig Tissue Sonicates

\begin{tabular}{|c|c|c|c|c|c|}
\hline Subjects & $\begin{array}{l}\text { Mean age } \\
\text { (range) }\end{array}$ & Proislets & Thyroid & Liver & Kidney \\
\hline Pre-clinical IDDM $(n=10)$ & $\begin{array}{c}27.4 \\
(10-48)\end{array}$ & $6.27 \pm 6.37^{*}$ & $2.20 \pm 1.91$ & $1.43 \pm 1.11$ & $1.17 \pm 0.75$ \\
\hline $\begin{array}{l}\text { Recent-onset clinical IDDM } \\
\quad(n=9)\end{array}$ & $\begin{array}{c}14.8 \\
(10-36)\end{array}$ & $4.61 \pm 3.84$ & $1.78 \pm 1.28$ & $1.01 \pm 0.41$ & $1.39 \pm 0.52$ \\
\hline $\begin{array}{l}\text { Other autoimmune disease } \dagger \\
\quad(n=8)\end{array}$ & $\begin{array}{c}40.4 \\
(22-59)\end{array}$ & $1.74 \pm 0.58$ & $1.37 \pm 1.07$ & $1.42 \pm 0.77$ & $1.63 \pm 0.71$ \\
\hline Normal $(n=5)$ & $\begin{array}{c}34.4 \\
(25-51)\end{array}$ & $1.39 \pm 0.47$ & $1.09 \pm 0.35$ & Not done & $0.95 \pm 0.54$ \\
\hline
\end{tabular}

\footnotetext{
* Mean \pm standard deviation.

$\dagger$ Graves' disease $n=4$, scleroderma $n=4$.
} 
Table III. T Cell Reactivity to Sonicated Proislets: Association With Islet Cell Autoantibodies

\begin{tabular}{|c|c|c|c|c|c|c|c|}
\hline \multirow[b]{2}{*}{ IDDM group } & \multirow{2}{*}{$\begin{array}{l}\text { T cell* } \\
\text { reactivity }\end{array}$} & \multicolumn{2}{|c|}{$\begin{array}{c}\text { ICA (JDF } \\
\text { units) }\end{array}$} & \multicolumn{2}{|c|}{$\begin{array}{c}\text { IAA (nU } \\
\text { insulin/ml) }\end{array}$} & \multicolumn{2}{|c|}{$64 \mathrm{KAb}$} \\
\hline & & $>20$ & $\leq 20$ & $>40$ & $\leq 40$ & + & - \\
\hline Preclinical & + & 12 & 3 & 2 & 13 & 11 & 4 \\
\hline$(n=22)$ & - & 3 & 4 & 2 & 5 & 4 & 3 \\
\hline Recent-Onset Clinical & + & 4 & 2 & 3 & 3 & 4 & 2 \\
\hline$(n=11)$ & - & 4 & 1 & 2 & 3 & 2 & 2 \\
\hline
\end{tabular}

* $\mathrm{T}$ cell reactivity was defined as positive if the median stimulation index of $\left[{ }^{3} \mathrm{H}\right]$ thymidine uptake exceeded the mean $+2 \mathrm{SD}$ of normal subjects.

as that of ICA $>20 \mathrm{JDF}$ units or of $64 \mathrm{KAb}$. Of the 15 subjects with $\mathrm{T}$ cell reactivity, $11(73 \%)$ had $64 \mathrm{KAb}$, and vice versa. In recent-onset subjects, the frequency of $T$ cell reactivity $(6 / 11$ or $55 \%)$ was not different from that of ICA $>20$ JDF units $(8 / 11$ or $73 \%)$ and $64 \mathrm{KAb}(6 / 10$ or $60 \%)$.

\section{Discussion}

Our results show that it is possible to measure, specifically, $\mathrm{T}$ cell reactivity to islet antigens in bulk culture of PBMC from preclinical IDDM and recent-onset IDDM subjects. The higher magnitude and frequency of $T$ cell reactivity in preclinical subjects is in accord with the evidence that autoimmunemediated beta cell destruction precedes the clinical onset of IDDM, at which time the majority of beta cells have been destroyed (1). The frequency of $\mathrm{T}$ cell reactivity to proislet antigens was comparable to that of $64 \mathrm{KAb}$ and of ICA $>20 \mathrm{JDF}$ units. ICA > 40 JDF units, a strong prognostic marker for development of clinical IDDM (13), was an absolute marker of T cell reactivity. Atkinson et al. (14) reported that $64 \mathrm{KAb}$ against human islets were present in up to $82 \%$ of 32 preclinical subjects of mean age $19.7 \mathrm{yr}$. Our somewhat lower frequency of 64 $\mathrm{KAb}$ could be because we used fetal pig proislets as the substrate and identified an older population of preclinical subjects of mean age of $29.2 \mathrm{yr}$. In screening first-degree relatives, the initial cohort of preclinical subjects we identified, those in the present study, was biased towards parents and older siblings and this accounts for the higher mean age. It would be desirable to know the frequency of $\mathrm{T}$ cell reactivity to human islets, but these studies are difficult to perform because of the problem of procuring organ donor pancreata and the need to match for HLA. Studies with fetal pig proislets are relevant in view of the potential of pig islet xenotransplants in established IDDM (15).

In contrast to demonstrating $\mathrm{T}$ cell reactivity to islet antigens directly in bulk culture of PBMC, others have provided evidence for islet-reactive $T$ cells in peripheral blood by generating $T$ cell lines $(8,9)$. Our ability to detect autoreactive $T$ cells in bulk culture requires fresh PBMC and autologous serum in the medium, although the reason for the latter has not been ascertained. In our preliminary study (10), intact proislets were used to stimulate peripheral blood $T$ cells but in the present study sonicated tissues were used because proislets vary in size and composition and we wished to standardize the antigen preparation. The stimulation indices were somewhat lower with sonicated than with intact proislets, which may relate to antigen degradation during sonication or storage at $-70^{\circ} \mathrm{C}$. A 64-kD autoantigen, glutamic acid decarboxylase (GAD), is present in fetal pig proislets (10) and to preserve at least its enzymatic activity samples must be stored with the cofactor pyridoxal-5-phosphate, which was not the case in this study.

Islet-reactive $\mathrm{T}$ cells in peripheral blood would be expected to be present at low frequency, perhaps in the order of 1 in $10^{4}-10^{5}$, but nonetheless they can be detected specifically, as shown, and with reasonable precision (10). The definition of T cell reactivity is based on an arbitrary cut-off value in the normal control group. Whether the lower reactivity of most normals is due to a low frequency of islet-reactive $T$ cells that are normally regulated by peripheral mechanisms of tolerance (16) remains to be determined.

A key question concerns the antigens responsible for $\mathrm{T}$ cell reactivity. It is noteworthy that $T$ cell reactivity to sonicated proislets was greater in magnitude and frequency than to human insulin, consistent with the view that insulin, at least in soluble form, is not a major antigenic component in the proislet sonicate. Fetal pig proislets not only contain abundant amounts of $\mathrm{GAD}(10)$ but also a separate $38-\mathrm{kD}$ protein which we have found is sometimes co-precipitated with GAD by IDDM Ig (H. DeAizpurua et al., unpublished). Further studies are required to define the relative contributions of GAD, the $38-\mathrm{kD}$ protein or other possible autoantigens (17) to $\mathrm{T}$ cell reactivity against fetal pig proislets, and determine whether the $38-\mathrm{kD}$ protein we detect by immunoprecipitation is identical to the $38-\mathrm{kD}$ insulin secretory granule membrane protein reported to stimulate $T$ cell clones from IDDM subjects (9).

$T$ cell reactivity in preclinical and recent-onset subjects was specific for sonicated proislets, with the exception of three HLA-DR3/4 females from each group whose stimulation indices to thyroid exceeded the mean +2 SD of the normal controls. This finding is not surprising given the well-known clinical clustering of autoimmune thyroid disease and IDDM. Five of these six females were adults but they had no family history or serological evidence of polyglandular autoimmunity. Nevertheless, we assume that they are demonstrating autoreactivity to a thyroid-specific antigen which has not yet been manifest by the presence of detectable autoantibodies.

The association of islet-reactive T cells with high titre ICA and with $64 \mathrm{KAb}$ suggests that $\mathrm{T}$ cell assays may be of value for predicting the development of clinical IDDM. This will need to be confirmed by prospective measurements of $T$ cell reactivity in first degree relatives with and without ICA, in parallel with autoantibodies and indices of insulin secretory capacity. The advent of recombinant GAD (18) and other candidate islet autoantigens (17) should allow $T$ cell assays to be refined to address the question whether $\mathrm{T}$ cell autoreactivity is a normal but regulated phenomenon and to facilitate the identification of the primary target autoantigen(s) in IDDM.

\section{Acknowledgments}

The authors would like to thank Drs. Jenny Couper, George Werther, Garry Warne, and John Court, as well as Vicky Stewart, RN, and Heather Margetts, RN, for their assistance with the recruitment of subjects at the Royal Children's Hospital and the Royal Melbourne Hospital, and Dr. Brian Tait for HLA typing. Margaret Thompson provided excellent secretarial and administrative assistance. David Cram criti- 
cally reviewed the manuscript. L. C. Harrison is a Senior Principal Research Fellow of the National Health and Medical Research Council of Australia. The study was financially supported by grants from the Victorian Health Promotion Foundation, the Juvenile Diabetes Foundation and the National Health and Medical Research Council.

\section{References}

1. Harrison, L. C., I. L. Campbell, P. G. Colman, N. Chosich, T. W. H. Kay, B. Tait, R. K. Bartholomeusz, H. DeAizpurua, J. L. Joseph, S. Chu, and W. E. Kielczynski. 1990. Type 1 diabetes: Immunology and Immunotherapy. $A d v$. Endocrinol. Metab. 1:36-94.

2. O’Reilly, L. A., P. R. Hutchings, P. R. Crocker, E. Simpson, T. Lund, D. Kioussus, F. Takei, J. Baird, and A. Cooke. 1991. Characterization of pancreatic islet cell infiltrates in NOD mice: effect of cell transfer and transgene expression. Eur. J. Immunol. 21:1171-1180.

3. Kay, T. W. H., I. L. Campbell, and L. C. Harrison. 1991. Characterization of pancreatic $\mathrm{T}$ lymphocytes associated with beta cell destruction in the nonobese diabetic (NOD) mouse. J. Autoimmunity. 4:263-276.

4. Mordes, J. P., J. Desemone, and A. A. Rossini. 1987. The BB rat. Diabetes/ Metabolism Reviews. 3:725-750.

5. Bottazzo, G-F., B. M. Dean, J. M. McNally, E. H. MacKay, P. G. F. Swift, and D. R. Gamble. 1985. In situ characterization of autoimmune phenomena and expression of HLA molecules in the pancreas in diabetic insulitis. $N$. Engl. J. Med. 313:353-360.

6. Wicker, L. S., B-J. Miller, and Y. Muller. 1986. Transfer of autoimmune diabetes mellitus with splenocytes from nonobese diabetic (NOD) mice. Diabetes. 35:855-860.

7. Koevary, S., A. Rossini, W. Stoller, W. Chick, and R. M. Williams. 1983. Passive transfer of diabetes in the BB/W rat. Science (Wash. DC). 220:727-28.

8. De Berardinis, P., M. Londei, R. F. L. James, S. P. Lake, P. H. Wise, and M Feldmann. 1988. Do CD4-positive cytotoxic T cells damage islet $\beta$ cells in type 1 diabetes? Lancet. ii:823-824.
9. Roep, B. O., A. A. Kallam, W. L. W. Hazenboz, G. J. Bruining, E. M. Bailyes, S. D. Arden, J. C. Hutton, and R. R. T. deVries. 1991. T-cell reactivity to $38 \mathrm{kD}$ insulin-secretory-granule protein in patients with recent-onset type 1 diabetes. Lancet. 351:1439-1441.

10. Harrison, L. C., H. DeAizpurua, T. Loudovaris T, I. L. Campbell, J. S. Cebon, B. D. Tait, and P. G. Colman. 1991. Reactivity to human islets and fetal pig proislets by peripheral blood mononuclear cells from subjects with preclinical and clinical insulin-dependent diabetes. Diabetes. 40:1128-1133.

11. Baekkeskov, S., H-J. Aanstoot, S. Christgau, A. Reetz, M. Solimena, M. Cascalho, F. Folli, H. Richter-Olesen, and P.-D. Camillo. 1990. Identification of the $64 \mathrm{~K}$ autoantigen in insulin-dependent diabetes as the GABA-synthesizing enzyme glutamic acid decarboxylase. Nature (Lond.). 347:151-156.

12. Vardi, P., S. A. Dib, M. Tuttleman, J. E. Connelly, M. Grinbergs, A Radizabeh, W. J. Riley, N. K. Maclaren, G. E. Eisenbarth, and J. S. Soeldner. 1987. Competitive insulin autoantibody assay: prospective evaluation of subjects at high risk for development of type 1 diabetes mellitus. Diabetes. 36:1286-1291.

13. Bonifacio, E., P. J. Bingley, M. Shattock, B. M. Dean, D. Dunger, E. A. M. Gale, and G-F. Bottazzo. 1990. Quantification of islet-cell antibodies and prediction of insulin-dependent diabetes. Lancet. 335:147-149.

14. Atkinson, M. A., N. K. Maclaren, D. W. Scharp, P. E. Lacy, and W. J. Riley. $1990.64000 \mathrm{Mr}$ autoantibodies as predictors of insulin-dependent diabetes. Lancet. 335:1357-1360.

15. Finke, E., P. Marchetti, L. Falqui, C. Swanson, M. McLear, B. Olack, D. Scharp, and P. Lacy. 1991. Large scale isolation, function and transplantation of islets of Langerhans from the adult pig pancreas. Transplant. Proc. 772-773.

16. Miller, J. F. A. P., G. Morahan, and J. Allison. 1989. Immunological tolerance: new approaches using transgenic mice. Immunol. Today. 10:53-57.

17. Castano, L., R. Russo, L. Zhou, M. A. Lipes, and G. S. Eisenbarth. 1991. Identification and cloning of a granule autoantigen (carboxypeptidase $\mathrm{H}$ ) associated with type 1 diabetes. J. Clin. Endocrinol. \& Metab. In press.

18. Cram, D. S., L. D. Barnett, J. L. Joseph, and L. C. Harrison. 1991. Cloning and partial nucleotide sequence of human glutamic acid decarboxylase cDNA from brain and pancreatic islets. Biochem. Biophys. Res. Commun. 176:12391244. 